\title{
紙質と印刷物の色調について
}

\author{
北越製紙株式会社 研究所 金子昇兵, 日 野 正 彦
}

\section{Relationship between Paper Qualities and Color Reproduction of Prints}

Hokuetsu Paper Mfg. Co., Ltd. Research Laboratory Shohei Kaneko and Masahiko Hino

\begin{abstract}
Evaluation of prints is finally performed by vision. However, we confirmed that the GATF system which is used for checking of the color of process inks in the ink industry is useful for that purpose. Then, we examined that how paper qualities influenced to the values of the GATF system.

In the all literatures on this problem, discussion has been done covering wide range from art paper to low grade paper. Hence, the authors have missed the evidence that a paper quality of each kind of paper influences differently to the color reproduction.

This paper is a report on fine paper. We found that the gloss, the oil absorbability, the light scattering ability, and the color specification of a white color of paper, in the order of increassing, give influence to the color reproduction. The color specification is a main factor. We proposed a new equation to indicate the color specification of a white color of paper. Using this value, we can estimate the color reproduction of prints which is influenced by a white color of pulp or effect of a whitener.
\end{abstract}

\section{1. 緒言}

印刷界では最近のカラー化に伴って色調に関する要 求が益々 Severe になり，市場では印刷物の極めてわ ずかな色の相違でその優劣があらそわれているのが現 状である。

印刷物の色調とそれに影響を执よぼす紙質との関係 についての文献は今までにも多くの人々によって発表 されている(1)〜 (9)，乙かしいずれもアート紙から新聞 下級紙に至る幅の広、範囲で現象を追求しているため,

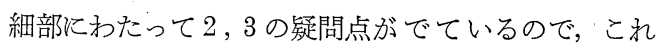
を究明する。また印刷物の色調に影響する主たる紙の 特性はその光学的性質によることを示し，紙の白さを 評価しそれによって色調を予告できる方法を確立する ことが目的で本実験を行った。

\section{2. 測定法および評価法}

\section{1 試料}

印刷物の色調は多くの紙の性質が複雑に影響し合っ ているのでその中の主要因の紙の性質についてはでき るだけシンプルな特性とするため，紙はすべて手抄き
シートを作りテスト紙とした。対象とした紙は上質紙 でコート紙については今回はふれない。性質は各々独 立して常識的な範用でわずかずつ違っている。例えば 吸油度が違っても紙の光沢, 白色度, 光の内部拡散な どは一定のもの, またパルプの白色度が同じで螢光染 料やブルーイングの程度だけを变えたもの, 吸油度と 光沢が共に変化したものなどである。吸油度その他が 同じで紙の構造に関係の深い光拡散係数だけが変化し たものなどである。これらは印刷物の色調に影響を特 よぼす紙質の全部であるといっても過言でない程の重 要性をるつものと判断される。使用した紙の性質の範 囲を示すため，製紙条件，測定法を含めてとの概略を 第一表に示した。

\section{2 印刷条件}

O印刷機 Original Heiderberg Cylinder KORD 64 オフ

○速度 4,500 枚/時

○印 圧 $0.08 \mathrm{~mm}$

○版 式 オフセットPS版ベタから 10\%まで

○インキ 東洋キング,プロセスG Cyan, Magenta.

O印刷室 $20^{\circ} \mathrm{C} \pm 1^{\circ} \mathrm{C}, \mathrm{R} \cdot \mathrm{H} 65 \% \pm 3 \%$ 


\section{第 1 表}

製紙条件 下記条件の一つまたはそれ以上の組み合わ せで条件を変える
1. パルプ白色度
79〜87 の範囲のもの
2. バ ソ ド
$2 \%$
3. コロパール
$3 \%$
4. ク $レ$ -
灰分 $0 \sim 20 \%$
5.メチルヴァイオレット9段階
6. クリスタルヴアィオレット 4 段階
7. マゼン タ 4 段階
8. 䖝 光染 料 5 段階
9. Wet プ レ ス 3 段階
10.フリーネス 3 段階

測定法と紙の性質の範囲

\begin{tabular}{|c|c|c|}
\hline 項 & 測 定 法 & 性質の範囲 \\
\hline 紙の光沢度 & $75^{\circ},-75^{\circ}$ & $5-15 \%$ \\
\hline 紙の吸油度 & JIS & $2-60$ \\
\hline 紙の白色度 & JIS ハンター & $79-84 \%$ \\
\hline 紙の光拡散係数 & $\begin{array}{l}\text { Kubelka and } \\
\text { Munk式の S 值 }\end{array}$ & $26-40$ \\
\hline 白 紙 効 率 & \multicolumn{2}{|l|}{ 本文 } \\
\hline 色 & \multicolumn{2}{|c|}{ 色差計 UCS 系の L.a.b } \\
\hline 濃 & \multicolumn{2}{|c|}{$\begin{array}{l}\text { WELCH } \text { の DENSICHRON } \\
\text { 反射濃度 }\end{array}$} \\
\hline 視 覚 判 定 & \multicolumn{2}{|c|}{ 本文（判定，規準，照明） } \\
\hline 印 & \multicolumn{2}{|l|}{ 本文（条件） } \\
\hline 色調 $\left(\begin{array}{l}(\text { 色相蠋り差 } \\
\text { 効率 }\end{array}\right)$ & \multicolumn{2}{|l|}{ 本 文 } \\
\hline
\end{tabular}

\section{3 印刷物の色の物理的評価}

印刷物の評価は最終的には主観, 感覚によって評価 されるから，これを物理量で客観的に評価することは 容易なことではないが，その基準を明確にして和かな ければならない。色を評価する表色系としてはいくつ かあるが，印刷物の主観的判定と最も相関するである ら思われる次の二つの表色系をとり上げた。

主としてインキメーカーが使用しているプロセスカ ラーの性能や，色修正などいわゆる製版とプロセスカ ラーだけを対象とした表色系を GATF が発表してい るが，これを印刷物の色調評価に使ら。これは感覚と の対応も簡明であり, 測定も数值の計算も容易である。

Wrattan Filter No. 47B, No. 58G, No. 25A を 装備した濃度計 (ここでは WELCH DENSICHRON) こより測定した三つの濃度值（最高 $\mathrm{H}$ ，中間 $\mathrm{M}$ ，最低 L）から次式により計算して完全なプロセスカラーか
らの色の偏りを示す色相誤差 (Hue Error), 色の純 粋さを示す濁り（Grayness）およびその性能を示す効 率 (Efficiency) を求めることができる。

$$
\begin{aligned}
& \text { 色相誤差 }=\frac{M-L}{H-L}(\%) \\
& \text { 濁 } \quad り=\frac{L}{H}(\%) \\
& \text { 効 } \quad \text { 率 }=1-\frac{L+M}{2 H}(\%)
\end{aligned}
$$

今一つの表色系は視感覚との相関が非常によいとい われている Recherd S. Hunter により工夫された色 差計を利用する方法である。ここで色の規準としては， インキメーカーが発表している原色インキのカラーパ ッチを, 得られるインキの理想值として, その $L, a$, $b$ を測定し, サンプルの $L_{1}, a_{1}, b_{1}$ との差すなわち理 想值加らの色差を算出して使うことにした。

すなお色色差 $\Delta E=\sqrt{\left(L-L_{1}\right)^{2}+\left(a-a_{1}\right)^{2}+\left(b-b_{1}\right)^{2}}$

この值が少さければ少さい程良好な発色を示す。

\section{4 視覚的評価と物理的評価の相関性の比較}

\section{第 1 図}
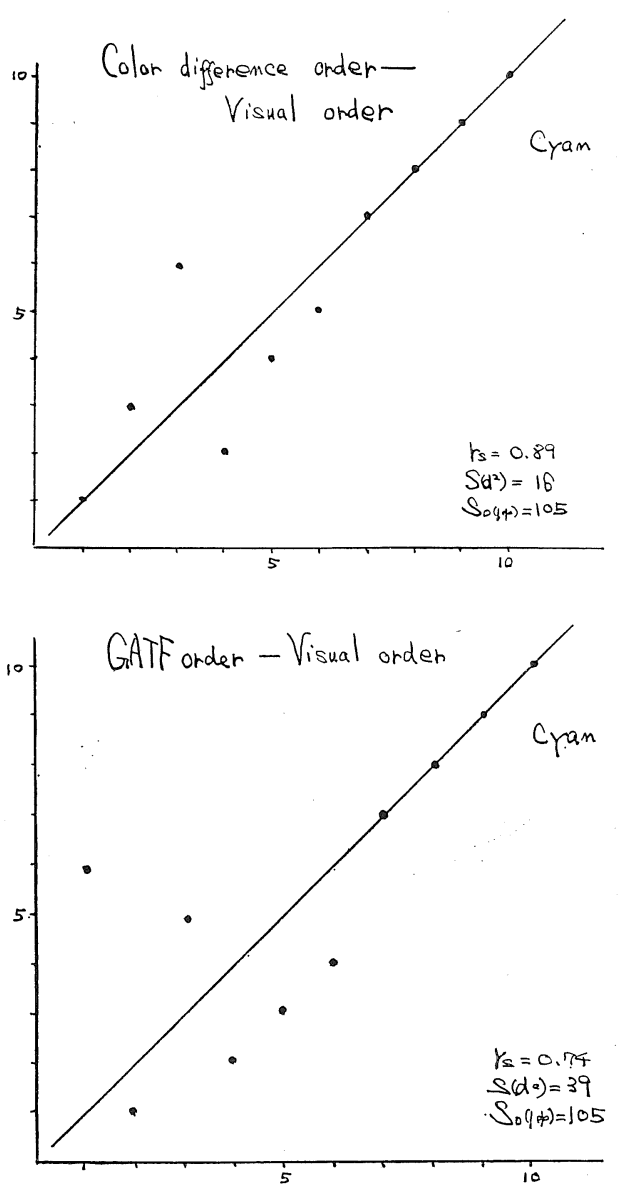

紙パ技協誌 第 25 巻第 8 号 

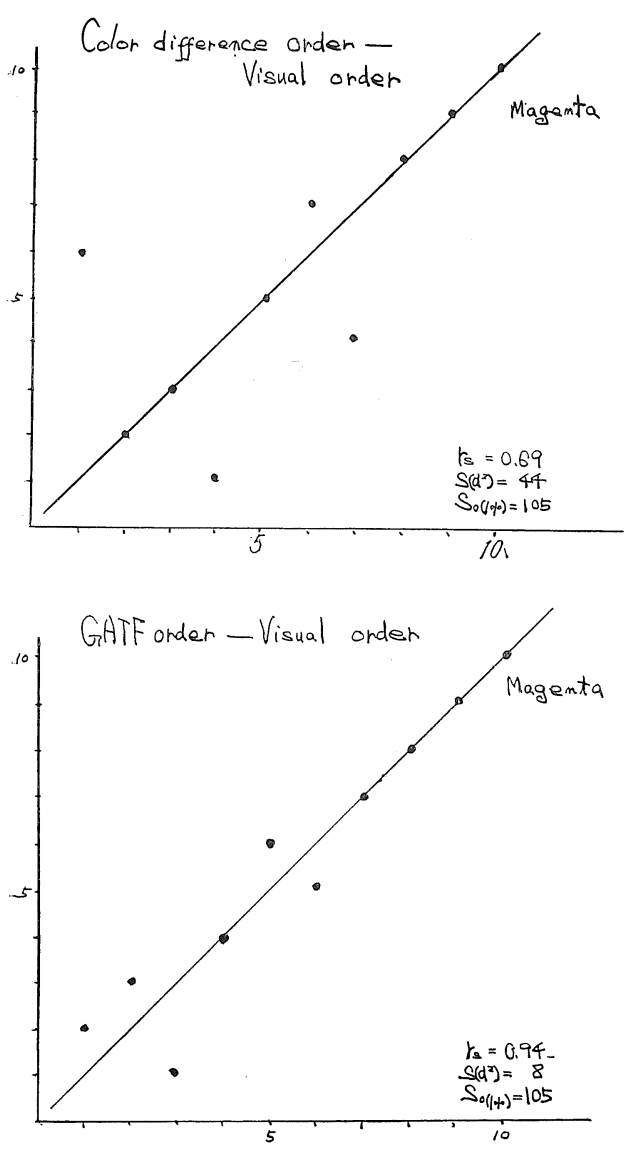

第 1 図はこれら二つの方法によって測定された值の ちち，どちらの方法が視感覚との相関性がよいかを実 験した結果を示したものである。

な打視感覚の判定規準を次のような観点に括いた。

1. 判定者, 識別能力の訓練を経た者 2 名の平均,

2. 印刷面の色の鮮明さ，コントラストの強さ，色 末ょび光沢の均一性

3. 判定者 2 名の判定順位の明らかな一致が見られ たためあえて一致性の検定は行ってない

この主観的な色調の印刷効果の順位と前記二つの物 理的表色系のそれぞれの相関関係を比較すると，スペ アマンの順位相関は1\%で極めて有意であり，総じて 色差によるより，GATF の表色系による方が，より 良いことが第1図により明らかである。

\section{3. 実験結果および考察}

\section{1 紙の光沢度の影響}

紙の光沢は必らずしも印刷面の光沢と相関がないこ とは大部分の人々による過去の経験的テストならびに 過去の文献(1)によっても明らかである。他の文献(6)で
第 2 圈

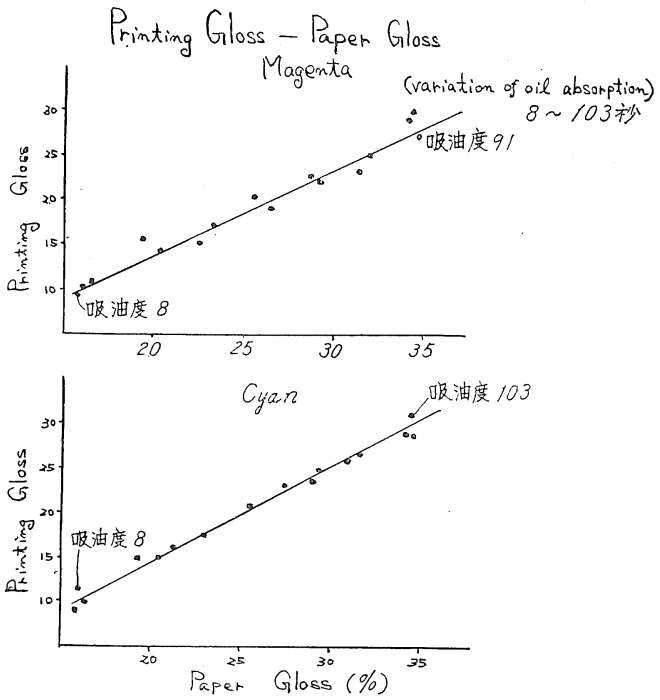

は色調に影響するものは印刷面光沢であり, 紙の光沢, 平滑，吸油度などは第二義的であると述べている。

しかし W. Christensen ${ }^{(9)}$ は紙の各性質中, 光沢 が最も色調に影響していると述べている。その他二, 三の文献でもいろいろの説が発表されている。

第 2 図は紙の光沢と印刷物光沢の関係を示したもの であるが，このサンプルは吸油度も 8 から 103 まで変 化しているので，紙光沢だけの影響を示すカーブは得

第 3 図
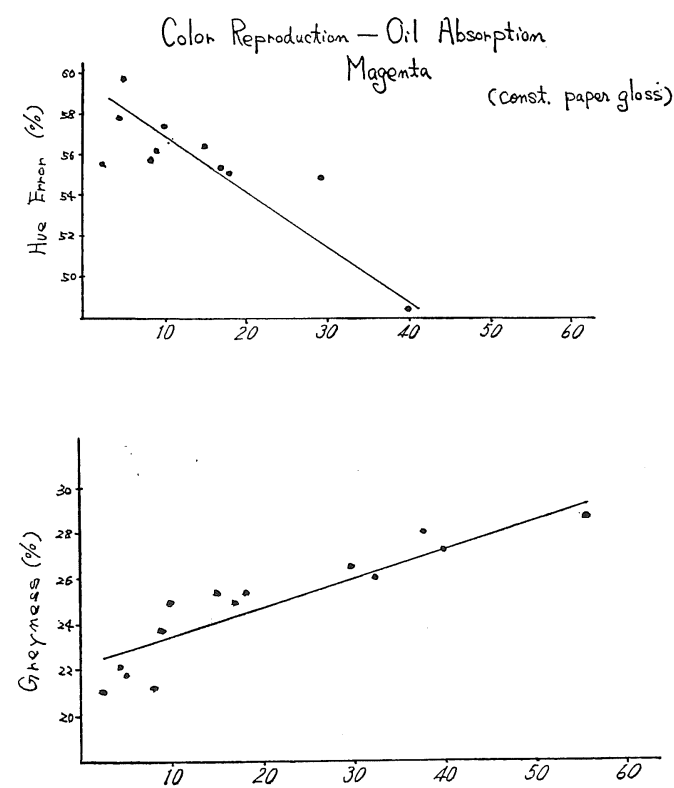


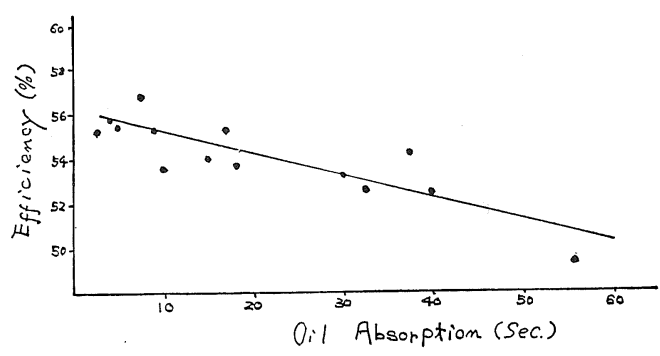

第 4 図
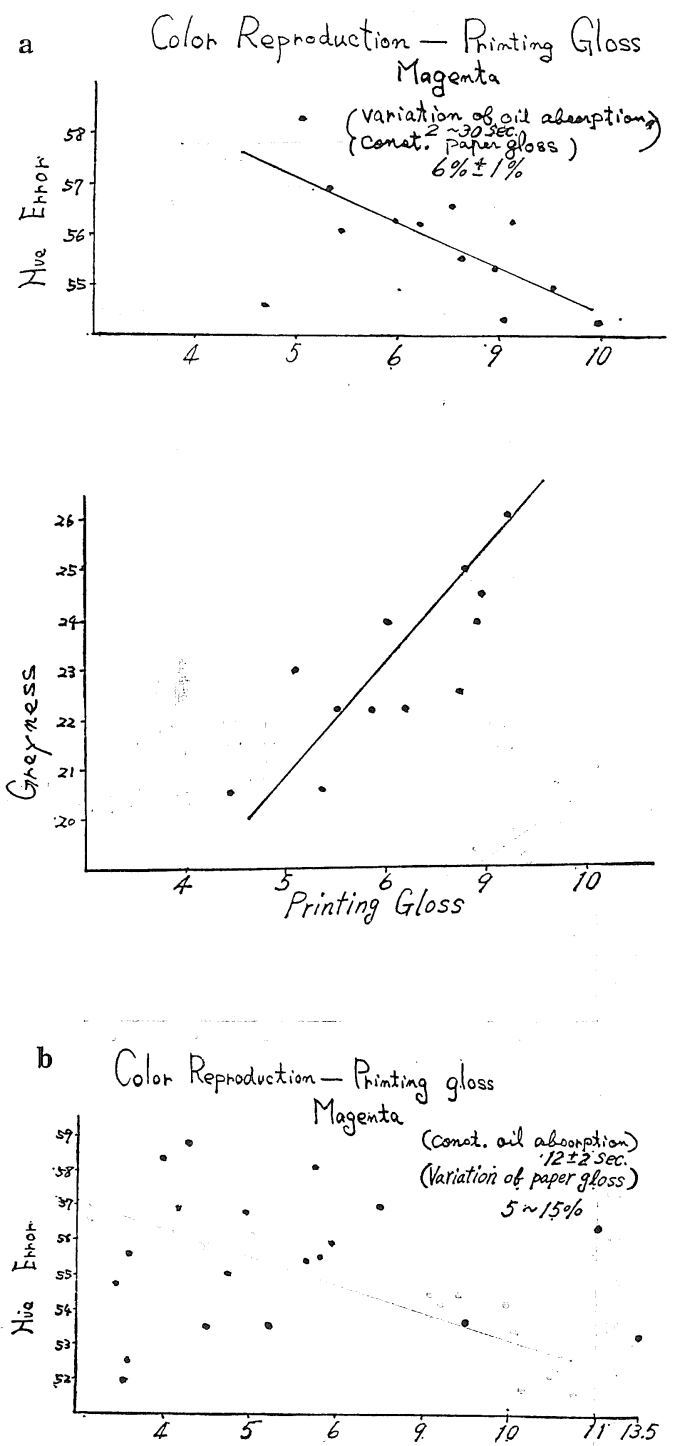

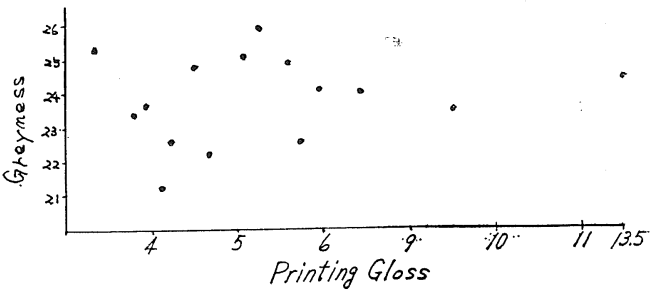

られなかった。他のサンプルで紙の光沢が一定，吸油 度が印刷光沢に特よぼす影響だけを見ると第 3 図のご とく明暸な相関関係がある。したがって前図のように 紙の光沢が高くかつ吸油度の大きい（非吸油性）紙は． この 2 つの特性が相乗されて印刷光沢を広範囲に高め ている。

次に印刷光沢が色調に和よぼす影響を第 4 図 a，b に示した。紙の光沢が一定で, 吸油度が変ったために. 印刷光沢が変化したサンプルでは，a図のように影響: が見られるが，吸油度一定で紙の光沢によって変動し た印刷光沢と色調とは無関係であった。

Wet press，吒解度などを種々に変光て作られた多 くのサンプルの中から，吸油度が大体一定のサンプル を抆取り，これらの紙の光沢は $5 \%$ 15\% (上質紙変 動範囲）に変化しているが色調との相関に得られなか. った。

\section{2 吸油度の影響}

上記の結果によってもすでに吸油度が影響すること は大体わかっているが，また種々の文献でも最も重要 視している。一方，W. Christensen ${ }^{(9)}$ は影響はない といっている。そこで更に詳細に実験することにした。 灰分量, Wet press, 吒解度などをいろいろ変光て 得た多くのサンプル中から，表面状態，光沢，色なぞ が極めて近似し，吸油度だけが変化したものを供試片 とした。

他の紙質を変えることなく，上質紙としては常識的 範囲に吸油度だけを変えた場合の結果を第 5 図に示し た。吸油度が少さく，すなわら吸収性が増すにつれて， 色相は理想值より少しずつずれてくるが濁りは少さく なるため色の効率は良くなる。これはインキフィルム をだんだん厚くして印刷したときと同じような現象が でている。マゼンタでは吸油度は色相誤差, シアンで はグレイネスへの影響が比較的大きい。吸油度が大き くなるにつれて濁りが大きくなり，全体としての色の 効率が低下していることは，これまでの文献などで見 られる現象と逆になっていることがわかる。

\section{3 紙の白色度の影響}

前節で吸油度や光沢の色調におよぼす影響は比較的 
第 5 図
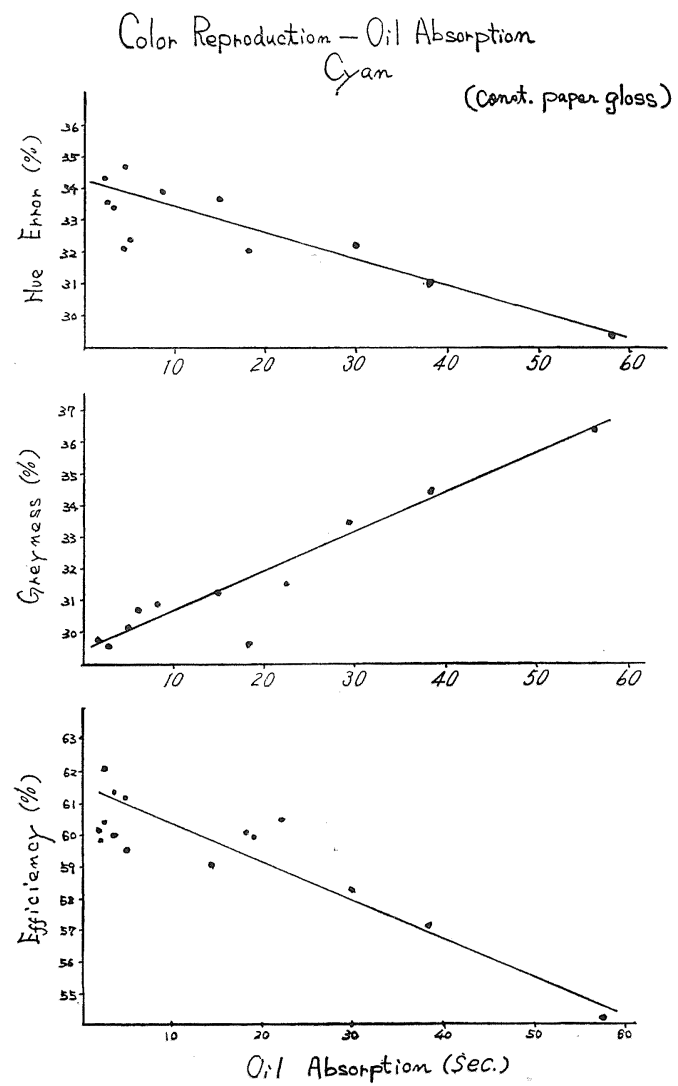

少さいことがわかる，それにもかかわらず市場のサン プルは依然としてかなり色相の差が感ぜられる。これ はインキをのせる基盤である紙の地色の影響に左右さ れるためである。すなわち次に述べる紙自身の白さ （白さの色合い）が重要な要素になっていることがわ 加る。

透明インキを使って印刷画像を生ずるメカニズムを 考察して見ると明らかなごとく, 第 6 図のように反射 体としての紙の色によって選択吸収，反射の様子がイ ンキの色調に影響していることがわかる。特に tone のある印刷ではインキと紙は複雑に作用乙合って印刷 画像を再現するから，インキや紙の色の表現特性と共 に両者を関連させる研究が必要である。

\section{紙の白さの評価}

紙の白さはその光学的性質中特に重要な要素に属し 本題の中心的課題となっている。紙は一般白さを保 つために青系の染料が添加され，あるいはまた䖝光染 料が用いられているが，これは印刷したときの色調に ぞのようそ影響するものであるうか，このような問題
第 6 図

The selective absorption, reflection of $\ln k$

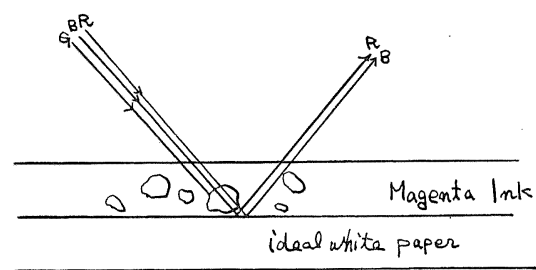

を明らかにするため，先ず紙の白色度評価方法を検討 した。

あるハンタ一白色度をもったパルプを用いて，これ に染料 (メチルバイオレット) でブルーイングする。 このサンプルを UCS 系の $L, a, b$ 色度図上にプロッ トすると第 7 図のように直線的変化していくことが わかる。また異った白色度のパルプを使ってブルーイ ングすれば，これも色度図上を同方向へ直線的に変化 していくまをた同種の紙にそれぞれ螢光染料を入れた ものの測定值をプロットすると別の方向へ移動して, 系統的なパターンが得られることを第 7 図は示してい る。ブルーイングしたものは，漂白を進めたパルプが

\section{第 7 図}

$L, a, Q$ chromaticity diagram of Paper

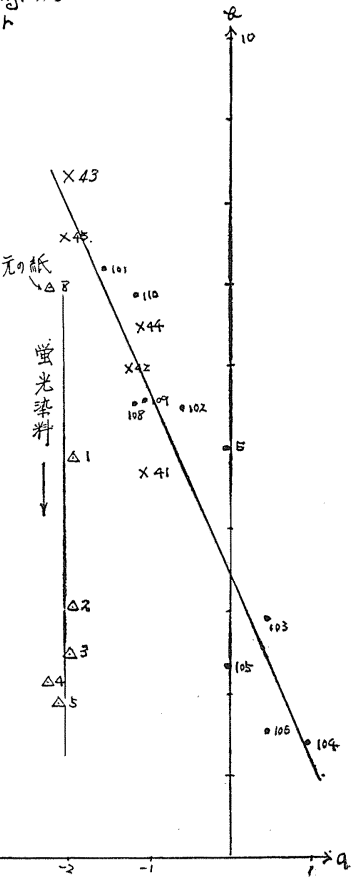

Whiteness Effficiency

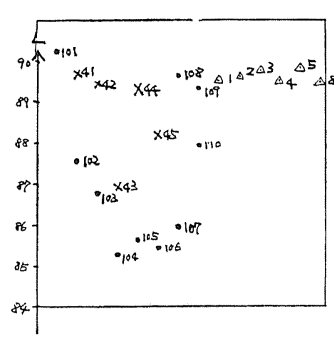

$$
100-\left\{(100-L)+2 \sqrt{a^{2}+Q^{2}}\right\}
$$


たどると同じ軌跡をたどっている。視感的な白さは図 表では中心のニュートラルに近く，加值の高いもの 程よい結果となっている。この色合いの紙は無彩色に 極めて近く，とりるな特さず市場的炕も好ましい紙と されていることがわかる。

白色子一種の色であり, これは色立体の頂上付近に 㐫る色であり，見た目の白さいわゆる視覚と最もよく 相関する白さを客観的汇評価するため，この図を数值 化することにした。視感との相関を種々，検討した結 果，中心への近ずきかたすなわち無彩色の度合（過去 の文献でもいろいろの方法が試みられている）を何倍 して重みすつけたがよいかを実験した結果，最終的 飞は次式觉得心。これを便宜上白紙効率と呼ぶことに した。

$$
\mathrm{W} \cdot \mathrm{EF}=100-\left[(100-L)+\left(2 \sqrt{a^{2}+b^{2}}\right)\right]
$$

\section{紙の白さの影響}

第 8 図はこの值と視覚との関倸をプロットしたもの

第 8 図

Whiteness ffficiancy onder Visual onder

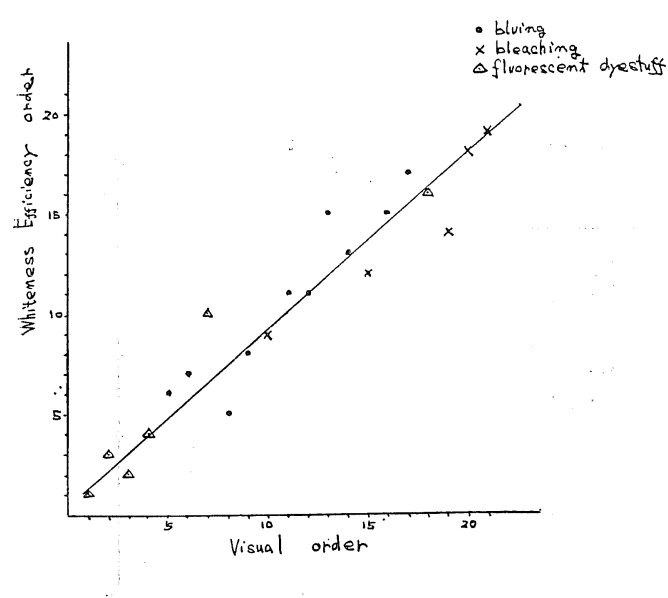

で高度に相関していることがわかる。ただし䖝光効果 飞ついての関連は色差計や濃度計の光源のスペクトル エネルギー分布を見ると紫外部が非常に少ないので, これを一律に考えて行くことに若干の危懼の念がある。 第 9 図は Magenta インキによる印刷で，紙の白紙 効率と色調の関係を示したものである。グレイネスは 一般には白紙効率が高い程少さくなるが，ブルーイン グしたものでは白紙效率が高いにもかかわらず，グレ イネスが高くなり，色の純粋さが低下している。しか し白紙効率との著るしい相関はむしろ Hue Error と の相関であり，したがって総合的ないわゆる色の効率
は Hue Error が主効果となって白紙効率が高い程良 好となっていることがわかる。これはブルーイング， 螢光染料の添加，パルプの漂白の程度を進めることが 適確に白紙効率を高めそ北によって色調を良くしてい ることがわかる。

次に Cyan の場合の印刷物について考察して見る， 第 10 図のようにブルーイングを進めたサンプルでは 白紙效率が高いにもかかわらずむしろ Hue Error が 若干大きい，こ机艺ルーイングに使用した染料が Violet 系のものを用いたためである。しかしブルー

\section{第 9 図}
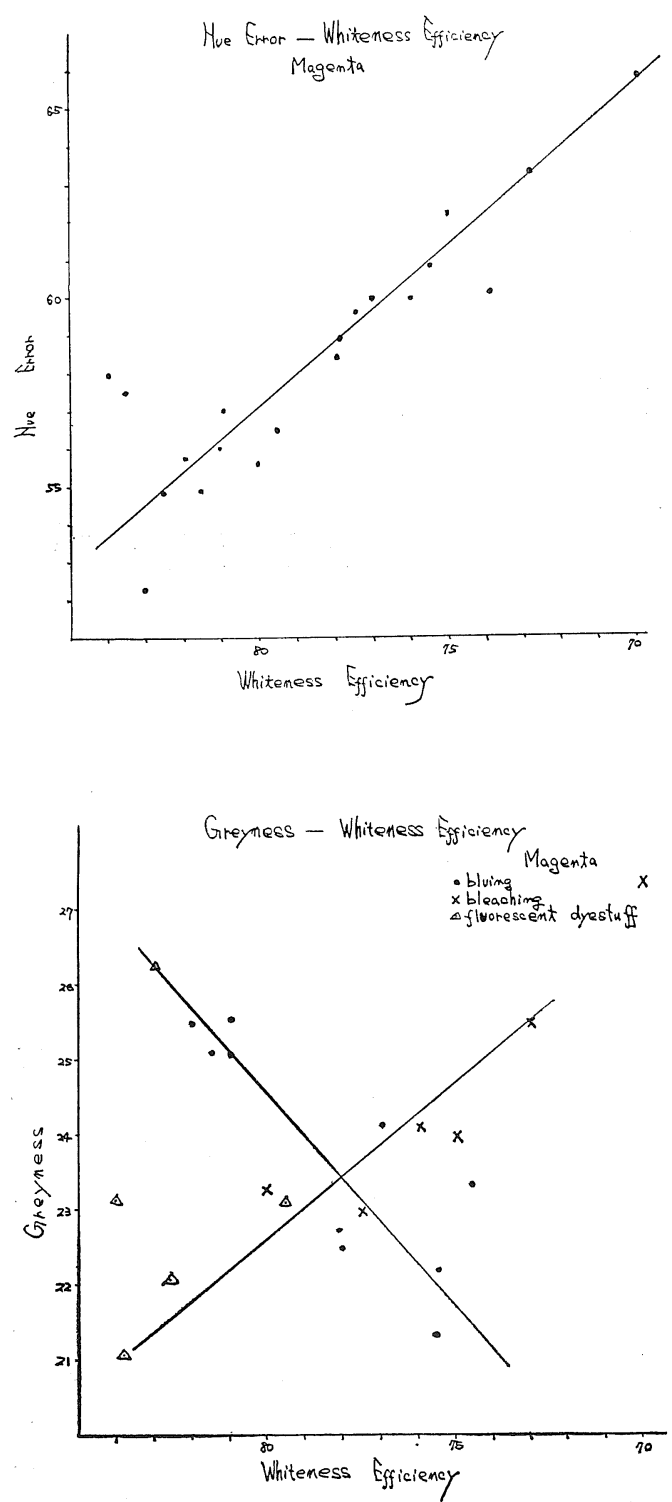


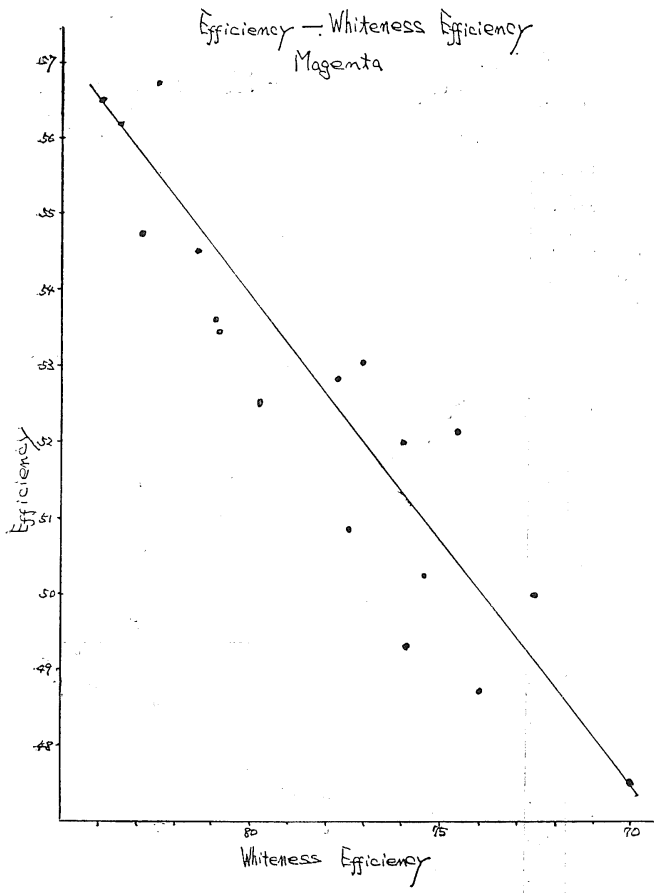

イングしないサンプルでは漂白を進めればパルプの黄 色度が下り，前述の $L, a, b$ 色度図のよらな軌跡を移 動して, 白紙効率が高くなり，それにつれて Magenta の場合と同様，Hue Error が明らが低下してより よい印刷物となる。Cyan では色相誤差と白紙効率と の相関は Magenta の場合のような著るしい相関関係 はないが，グレイネスとの相関は全サンプルを通して 比較的高く，これが色の效率に括よぼす主効果となっ ている。

以上総活すると用紙の白紙効率は Magenta では Hue Error, Cyan では Greyness との相関関係が特 飞高く，これが印刷物の色調を良好にせしめている主 なる要因となっていることがわかる。

従来のいわゆるハンター白色度ブライトネスと色調 との関係の一例を第 11 図にプロットした。ここでは 両者の相違を見出すことができない。

以上のことから白色度の評価方法として白紙効率が 有効であり，その值が高い程，印刷物の色調が良好に なり，すなわち紙の白紙効率を測定することにより色 調を予測することができる。

\section{4 紙の光拡散係数の影響}

紙の光の内部拡散がその印刷物のハーフトーンのリ プロダクションにおよ洔す影響は大きく，そのため色 刷の印刷物の色調にかなり影響をおよぼすことが示唆
第 10 図
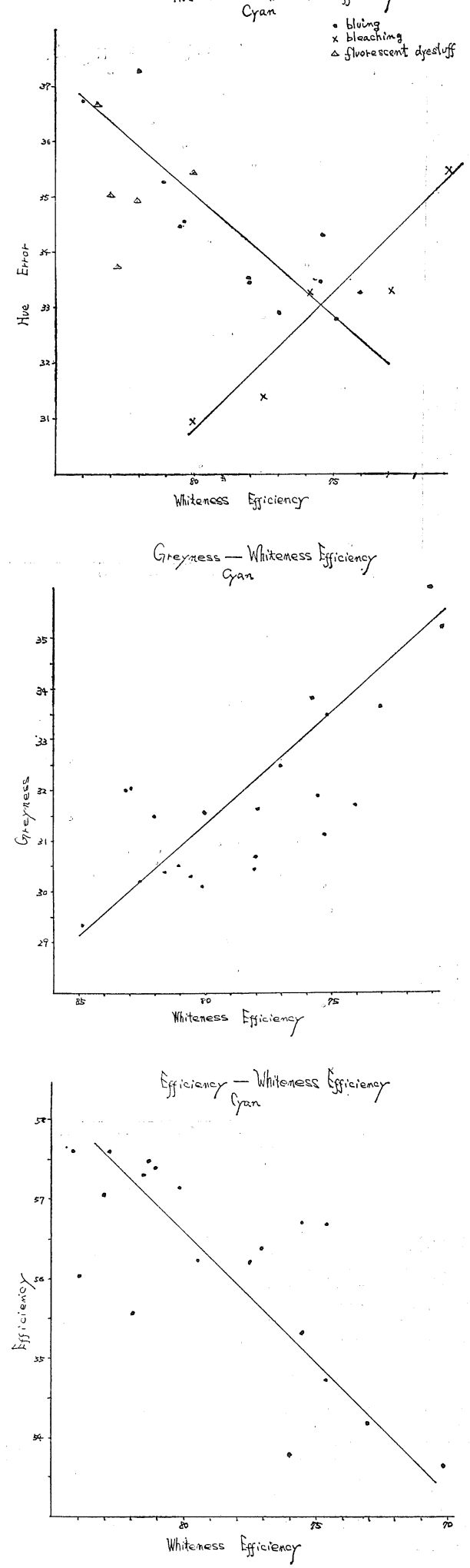
第 11 図

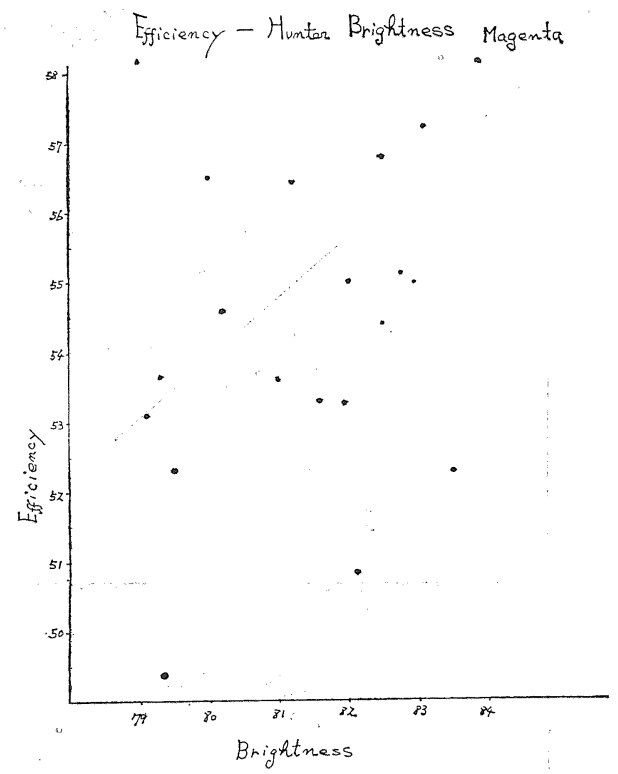

Efficiency-Hunter Brightness Gan

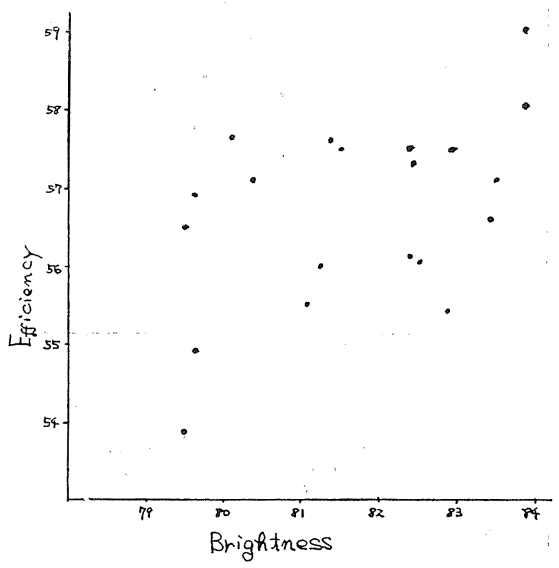

されている(10)ので，その関係を実験した。

この実験で使う紙は白色度，光沢，吸油度などを一 定にして光拡散係数だけを異にした手抄きシートを作 り，その印刷物から色調との関係を求めた。

光拡散係数は Kubelka und Munk の理論の方程 式からのS 值を使っている。第 12 図はこの関係を示 したもので，拡散係数がわずかに増加するにつれて， 色調は確実に良好となることがわかる。 $\mathrm{S}$ 值はクレー 含量,・フ・リーネス、ウェットプレスが互いに影響して 変化する。
第 12 図
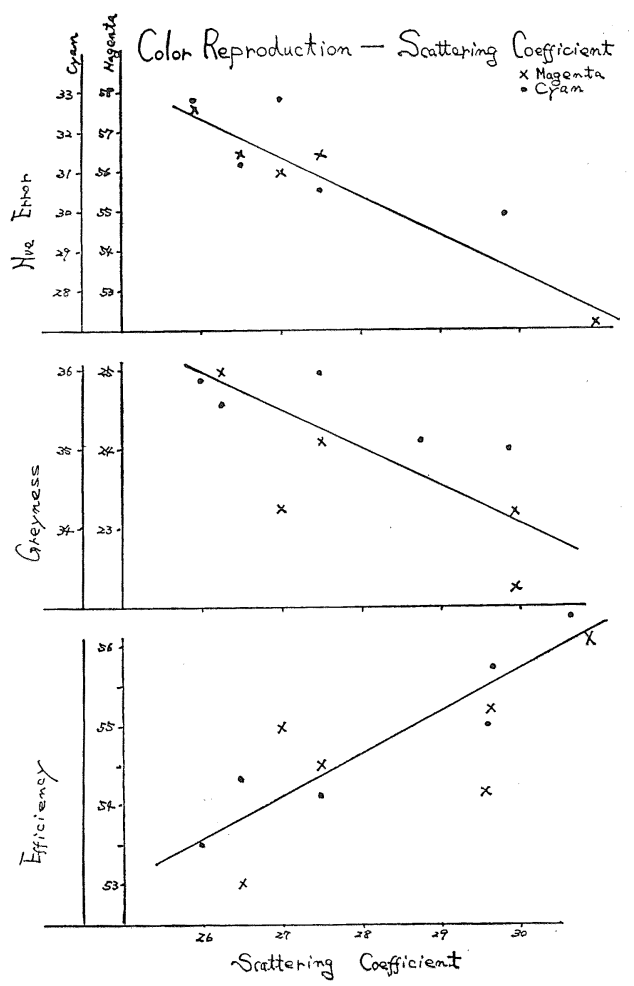

\section{4.むす び}

上質紙として市販される紙の中では，その性質が著 しく異なることはない。しかしそのわずかな性質の变 動で印刷物の色調が変る。

色調に影響する紙の主なる性質について，両者の関 係を詳細に調べたもので，個々の性質を単独にとり上 げてみると過去の文献で見られた結果と逆な現象も見 出された。また単独では影響を特よぽさないが，2つ の性質が重なって初めてある程度大きな影響力をあら わす場合もあり，性質の範囲のとり方，一つまたはそ れ以上の性質のとり方の相違などによっていろいろの 説がでていることがわかった。

上質紙では紙の白さ，色合いのわずかな変化が比較 的色調に特よぼす影響が大きいので，その白さを評価 する方法が大切であり，それによって印刷物の色調効 果を予測できた。

\section{文献}

(1) J. Abelsen; Tappi 43, 202A-32A (1960)

(2) Wade, E. ; Tappi 42, No.6, 194A-65A (1960)

(3) Alvory W. Beecroft; P.T.J. July 25 (1954) 
(4) Otto Brwns \& Olle Swanberg; P.P.M.C. No. 3 T-181-87 (1962)

(5) 高烟伝; 千葉大学工業短大研究報告 Vol. 3 No. 3 p. 53 (1962)

（6）烟幸徳；日本印㕞学会論文集 Vol. 8 No. 22 p. 73 (1965)

(7) 村上勇夫訳; 日本印刷学会論文集 Vol. 8 No. 22 p. 109 (1965)
(8) Frank, M. Preucil ; Tappi $45[10] 823 \sim 826$ (1962)

(9) Chr. W. Christensen; Advan Printing Sci. Technol. 4, 438 444 (1967)

(10) 分島拓，国司龍郎，金子昇兵； J.O.S.A Vol. 58 p. $272-273$ (1969)

（原稿受付 昭 46. 1. 11）
新製品紹介

$$
\begin{aligned}
& \text { 新方式による新製品! } \\
& \text { 精 密 濾 過 装 置 } \\
& \text { ユミックナーY S 型 }
\end{aligned}
$$

当社が新しく開発した糖密濾過装置は濾材 （湯浅電池株式会社製，商品名ユミクロン） の特性を生かし，工場廃液中に含まれている 有害重金属を効率的に，さらに連続自動的に 排出基準值以下に除去することのできる装置 です。

\section{○フィルターとしてのユミクロンの特長}

1. 平均孔径が小さく, 微粒子を殆んぞ完全に除去で きます。

品種により, 平均孔径が $0.1 \mu$ のものから $5 \mu$ の ものまであります。

2. 厚みは薄く $(0.1 \sim 0.2 \mathrm{~mm})$, 機械的強度は堅牢で す。

3. 濾布プレコート材と比較して，流量が多量です。

4. 逆洗しやすく，目づまりが生じにくい。

5. ニミクロンに附着したスラッジの剥離ぶ極めて容

\begin{tabular}{|c|c|c|}
\hline 濾材 & 流量比 & $\begin{array}{l}\text { 逆洗使用の時濾液の } \\
\text { 力 } \quad \text { : 浱 度 }\end{array}$ \\
\hline 濾 布 $\mathrm{A}$ & 1 & 0.5 PPM \\
\hline 濾 布 B & 1.5 & $0.5 \mathrm{PPM}$ \\
\hline ユミクロン & 3 & 0.02 PPM \\
\hline
\end{tabular}
易です。

6. 耐酸性，耐アルカリ性です。

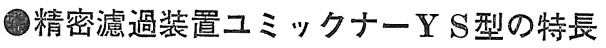

1. 凝集剤を用いない新しい処理方法による精密滤過 なので，スラッジが少なく，廃妄物が少量です。

2. 標準型の濾布の取換光は 3 分以内でできます。

3. コンパクトにできているので，据付面積が少なく てす文すす。

4. 連続自動式なので，殆んど人手を要しません。

5. 経費が少なくてすみます。

\section{前処理の必要性}

ニミクロンは有害重金属を微子粒として濾過するも ので, 従って最適な $\mathrm{P} \mathrm{H}$ 調整は慎重に行ならことによ り, 有害対象金属イオンを固形化沈殿物し, 生成沈殿 物の粒子をできるだけ大きくすることが有利です。

\section{株式会社 島 崎 製 作 所}

本社営業所 東京都荒川区西日暮里 2-24-2 TEL 東京(802) 3741 (代) 